\title{
APLIKASI PUPUK ORGANIK UNTUK MENINGKATKAN PERTUMBUHAN KACANG TANAH (Arachis hypogaea $\mathrm{L}$ )
}

\author{
APLICATION OF ORGANIC FERTILIZER TO INCREAST THE GROWTH OF PEANUTS (Arachis \\ hypogaea $\mathrm{L}$ )
}

\author{
Ahmad Raksun* dan Lalu Japa \\ Program Studi Pendidikan Biologi, Jurusan Pendidikan MIPA, FKIP Universitas Mataram. \\ Jalan Majapahit No 62 Mataram, 83125, Indonesia \\ *Email: ahmadunram@unram.ac.id
}

Diterima: 04 September 2018. Disetujui: 24 September 2018. Dipublikasikan: 30 September 2018

\begin{abstract}
Abstrak. Penelitian tentang aplikasi pupuk organik untuk meningkatkan pertumbuhan kacang tanah telah dilaksanakan di Desa Sukarare Kabupaten Lombok Tengah. Penelitian ini bertujuan untuk mengetahui: (1) pengaruh pupuk organik terhadap pertumbuhan kacang tanah, (2) dosis optimum pupuk organik agar kacang tanah dapat tumbuh secara optimal. Dalam penelitian ini digunakan rancangan acak lengkap dengan 8 ulangan. Hasil penelitian menunjukkan bahwa (1) aplikasi pupuk organik dapat meningkatkan pertumbuhan kacang tanah, (2) Penggunaan dosis pupuk organik 2,0 kg/10 kg tanah memberikan hasil yang lebih baik dibandingkan perlakuan lainnya.
\end{abstract}

Kata kunci: Pupuk organik, pertumbuhan, kacang tanah

Abstract. A research about the application of organic fertilizer to increase the growth of peanuts has done in Sukarare Village Central Lombok. The objective of this research are: (1) to know the effect of organic fertilizer to the growth of peanuts, (2) to know the dosage of organic fertilizer in oder that peanuts can grow optimally. Completly randomized design with 8 replicates were used in this research. The result of this research are: (1) the application of organic fertilizer can increas the growth of peanuts, (2) Aplication 2,0 $\mathrm{kg}$ organic fertilizer/10 $\mathrm{kg}$ of soil cause the better growth than other treatment.

Keywords: organic fertilizer, growth, peanuts

\section{PENDAHULUAN}

Pupuk organik adalah pupuk yang berasal dari bahan organik. Bahan organik tersebut dapat berupa kotoran hewan, daun-daun tumbuhan, serbuk gergaji, jerami padi dan lain-lain. Aplikasi pupuk organik pada lahan pertanian memiliki berbagai manfaat. Bahan organik mempunyai peran dalam memeperbaiki sifat fisika dan kimia tanah melalui stabilitas struktur, infiltrasi air, kadar air, suhu, aktivitas mikrobia dan penetrasi akar [1]. Selain itu bahan organik dalam tanah berpengaruh terhadap sifat kimia tanah yang secara umum berpengaruh tarhadap penyediaan hara bagi tumbuhan dan merupakan sumber hara N, P dan S

Berbagai hasil penelitian menunjukkan, bahwa aplikasi pupuk organik pada lahan pertanian berdampak positif terhadap pertubuhan dan produksi tanaman. Penggunaan pupuk organik berpengaruh nyata terhadap parameter tinggi batang tanaman, diameter batang, indeks luas daun, panjang tongkol dan bobot segar tongkol per hektar tanaman jagung manis [2, 3]. Perlakuan pupuk organik kotoran ayam 15 ton per hektar dalam larikan mampu meningkatkan produksi jagung manis hingga 21,3\% dengan produksi yang mencapai 14,67 ton per hektar dibandingkan dengan pupuk anorganik (kontrol) [4]. Pemberian pupuk organik kompos kotoran ayam bepengaruh nyata pada semua variabel pengamatan kecuali panjang tanaman bawang merah. Pemberian pupuk kandang ayam dosis 45 ton per hektar menghasilkan bobot segar total tanaman sebesar 2,93 ton per hektar pada kondisi penanaman di lahan dan pemberian kompos kotoran ayam dengan dosis yang sama menghasilkan bobot segar sebesat 2,10 ton per hektar pada kondisi penanaman di polybag [5].

Untuk mengetahui pengaruh aplikasi pupuk organik terhadap pertumbuhan kacang tanah maka peneliti melakukan penelitian tentang aplikasi pupuk organik untuk meningkatkan pertumbuhan kacang tanah yang dilakukan di Desa Sukarare Kabupaten Lombok Tengah. Adapun tujuan dilaksanakannya penelitian ini adalah untuk mengetahui: (1) pengaruh aplikasi pupuk organik terhadap pertumbuhan kacang tanah, (2) dosis optimum pupuk organik agar kacang tanah dapat tumbuh secara optimal.

\section{BAHAN DAN METODE}

Bahan-bahan yang digunakan dalam penelitian ini adalah benih kacang tanah, tanah sawah sebagai media tanam, pupuk organik dan air. Sedangkan alat-alat yang digunakan adalah 
penggaris, alat tulis menulis, cangkul, ember plastik dan gayung. Dalam penelitian ini digunakan rancangan acak lengkap dengan 8 ulangan Penggunaan pupuk organik terdiri atas 6 level yaitu: $\mathrm{P}_{\mathrm{o}}=$ tanpa pemberian pupuk organik (kontrol), $\mathrm{P}_{1}=$ pemberian $0,4 \mathrm{~kg}$ pupuk organik $/ 10$ $\mathrm{kg}$ tanah, $\mathrm{P}_{2}=$ pemberian $0,8 \mathrm{~kg}$ pupuk organik $/ 10$ $\mathrm{kg}$ tanah, $\mathrm{P}_{3}=$ pemberian $1,2 \mathrm{~kg}$ pupuk organik $/ 10$ $\mathrm{kg}$ tanah, $\mathrm{P}_{4}=$ pemberian $1,6 \mathrm{~kg}$ pupuk organik $/ 10$ $\mathrm{kg}$ tanah, $\mathrm{P}_{5}=$ pemberian $2,0 \mathrm{~kg}$ pupuk organik $/ 10$ $\mathrm{kg}$ tanah, $\mathrm{P}_{6}=$ pemberian $2,4 \mathrm{~kg}$ pupuk organik $/ 10$ $\mathrm{kg}$ tanah [6].

Parameter pertumbuhan yang diukur adalah panjang daun, lebar daun dan tinggi batang yang diukur pada saat tanaman berumur 40 hari setelah tanam. Data kuantitatif parameter pertumbuhan yang diukur dianalisis dengan analisis sidik ragam dan uji lanjut dengan Uji Beda Nyata Terkecil [6].

\section{HASIL DAN PEMBAHASAN}

Setelah tanaman kacang tanah berumur 40 hari, dilakukan pengukuran parameter pertumbuhan yang meliputi panjang daun, lebar daun dan tinggi batang tanaman kacang tanah. Data kuantitaif hasil pengukuran parameter pertumbuhan disajikan pada tabel berikut

Tabel 1. Rerata panjang dan lebar daun kacang tanah pada umur 40 setelah tanam akibat Perlakuan pupuk organik

\begin{tabular}{ccc}
\hline Perlakuan & $\begin{array}{c}\text { Panjang Daun } \\
(\mathrm{mm})\end{array}$ & $\begin{array}{c}\text { Lebar Daun } \\
(\mathrm{mm})\end{array}$ \\
\hline $\mathrm{P}_{0}$ & 52 & 26 \\
$\mathrm{P}_{1}$ & 55 & 29 \\
$\mathrm{P}_{2}$ & 58 & 30 \\
$\mathrm{P}_{3}$ & 62 & 32 \\
$\mathrm{P}_{4}$ & 65 & 32 \\
$\mathrm{P}_{5}$ & 68 & 35 \\
$\mathrm{P}_{6}$ & 67 & 35 \\
\hline
\end{tabular}

Tabel 2. Rerata tinggi batang kacang tanah pada umur 40 setelah tanam akibat perlakuan pupuk organik

\begin{tabular}{cc}
\hline Perlakuan & Tinggi Batang $(\mathrm{cm})$ \\
\hline $\mathrm{P}_{0}$ & 23 \\
$\mathrm{P}_{1}$ & 25 \\
$\mathrm{P}_{2}$ & 26 \\
$\mathrm{P}_{3}$ & 27 \\
$\mathrm{P}_{4}$ & 30 \\
$\mathrm{P}_{5}$ & 32 \\
$\mathrm{P}_{6}$ & 32 \\
\hline
\end{tabular}

Selanjutnya untuk mengetahui pengaruh pemberian pupuk organik terhadap panjang dan lebar daun kacang tanah maka dilakukan analisis sidik ragam dan uji lanjut dengan uji beda nyata terkecil [6]. Hasil analisis sidik ragam menunjukkan bahwa aplikasi pupuk organik berpengaruh nyata terhadap panjang daun dan lebar daun kacang tanah pada umur 40 hari setelah tanam.

Data pada Tabel 2 menunjukkan bahwa tinggi batang terendah terdapat pada perlakuan $\mathrm{P}_{0}$ dan tinggi batang tertinggi terdapat pada perlakuan $\mathrm{P}_{5}$ dan $\mathrm{P}_{6}$. Selanjutnya hasil analisis sidik ragam menunjukkan bahwa aplikasi pupuk organik berpengaruh nyata terhadap tinggi batang tanaman kacang tanah pada umur 40 hari setelah tanam.

Hasil analisis data menunjukkan bahwa kacang tanah yang tumbuh pada media tanpa pupuk organik memiliki rerata panjang daun, lebar daun dan tinggi batang masing-masing adalah $52 \mathrm{~mm}, 26$ $\mathrm{mm}$ dan $23 \mathrm{~cm}$. Selanjutnya pada media yang diberi pupuk organik, rerata semua parameter yang diukur mengalami peningkatan sejalan dengan meningkatnya kadar pupuk organik yang diberikan pada masing-masing unit percobaan, namun demikian mulai dari perlakuan $2,0 \mathrm{~kg}$ sampai dengan perlakuan $2,4 \mathrm{~kg}$ pupuk organik $/ 10 \mathrm{~kg}$ tanah, rerata semua parameter yang diamati tidak menunjukkan adanya peningkatan secara nyata. Terhambatnya pertumbuhan tanaman kacang tanah pada media tanpa perlakuan pupuk organik disebabkan karena rendahnya ketersedian unsur hara pada media tersebut. Selanjutnya pemberiaan pupuk organik menyebabkan makin tersedianya unsur hara terutama sulfat, posfat dan nitrat yang berasal dari hasil degradasi sampah organik yang dijadikan bahan baku pembuatan pupuk organik. Selain itu penambahan pupuk organik dapat memperbaiki sifat biologi, fisika dan kimia tanah. Dengan demikian aplikasi pupuk organik dapat memacu pertumbuhan tanaman. Stevenson [7] menjelaskan bahwa hasil dekomposisi bahan organik dalam tanah dapat meningkatkan ketersediaan hara $\mathrm{N}, \mathrm{S}$ dan $\mathrm{P}$, meningkatkan daya menyimpan air, meningkatkan daya buffer tanah, meningkatkan pertukaran kation, dan tekstur tanah menjadi lebih baik. Proses dekomposisi bahan organik oleh mikrobia akan dilepaskan unsur hara $\mathrm{N}, \mathrm{P}$ dan $\mathrm{S}$ yang dapat digunakan oleh tumbuhan [1].

Hasil analisis sidik ragam pengaruh pemberian pupuk organik terhadap semua parameter yang diukur menunjukkan bahwa aplikasi pupuk organik di lahan pertanian Desa Sukarare berpengaruh nyata terhadap semua parameter yang diukur. Hasil penelitian ini sejalan dengan hasil penelitian lainnya. Perlakuan perendaman bibit rumput laut dalam larutan pupuk organik cair memberikan dampak positif terhadap pertumbuhan bibit rumput laut Euchema cottonii [8]. Pemberian pupuk kandang 30 ton/ha yang dikombinasikan dengan kapur 2 ton/ha menghasilkan pertumbuhan tanaman terbaik dengan rataan tinggi tanaman $80,7 \mathrm{~cm}$, jumlah cabang primer 33,4 buah, diameter tajuk $105,7 \mathrm{~cm}$ dan produksi terna 25,2 ton/ha. Hasil tersebut berbeda nyata dengan perlakuan control dengan 
rataan tinggi tanaman $57,3 \mathrm{~cm}$, jumlah cabang primer 20,9 buah, diameter tajuk $67,4 \mathrm{~cm}$ dan produksi terna 6,1 ton/ha [9]. Pemberian pupuk organik dapat meningkatkan pertumbuhan bibit jambu mete [10], kedelai [11] dan tomat [12]. Pemberian pupuk organik biogreen granul dapat memperbaiki sifat fisik, kimia dan biologi tanah, berpengaruh positif terhadap pertumbuhan dan hasil tanaman bawang merah pada tanah dengan kandungan organik rendah. Pemupukan dengan dosis $4000 \mathrm{~kg} / \mathrm{ha}$ biogreen granul dapat meningkatkan produksi sebesar $23 \%$ atau selisih hasil sebesar 2,8 ton/ha dibandingkan dengan perlakuan kontrol [13]. Pemberian pupuk organik Biogreenex lewat daun dapat meningkatkan kualitas hasil tanaman sawi (kandungan klorofil meningkat $16 \%$, luas daun $76 \%$ dan hasil yang dapat dipasarkan $16 \%$ [14]. Pemberian berbagai dosis pupuk organik bokashi berpengaruh nyata terhadap tinggi tanaman kedelai [15].

Hasil Uji Beda Nyata Terkecil menunjukkan bahwa untuk semua parameter pertumbuhan yang diukur (panjang daun, lebar dau dan tinggi batang tanaman kacang tanah), perlakuan $\mathrm{P}_{5}$ (aplikasi $2.0 \mathrm{~kg}$ pupuk organik $/ 10 \mathrm{~kg}$ tanah) memberikan hasil yang berbeda nyata dengan $\mathrm{P}_{0}$ (kontrol), selanjutnya perlakuan $\mathrm{P}_{5}$ tidak berbeda nyata dengan perlakuan $\mathrm{P}_{6}$. Hasil analisis tersebut menunjukkan bahwa kadar optimum pupuk organik yang perlu diberikan pada lahan pertanian Desa Sukarare Kabupaten Lombok Tengah untuk meningkatkan pertumbuhan kacang tanah adalah 2,0 kg pupuk organik untuk setiap $10 \mathrm{~kg}$ tanah.

\section{KESIMPULAN}

Dalam penelitian ini dapat disimpukan bahwa: (1) aplikasi pupuk organik pada lahan pertanian Desa Sukarare berpengaruh nyata terhadap panjang daun, lebar daun dan tinggi batang tanaman kacang tanah, (2) Penggunaan dosis pupuk organik 2,0 $\mathrm{kg} / 10 \mathrm{~kg}$ tanah memberikan hasil yang lebih baik dibandingkan perlakuan lainnya untuk semua parameter pertumbuhan.

\section{DAFTAR PUSTAKA}

[1] Jooetono. 1991. Biologi dan Biokimia Peruraian Bahan organik Tanah. Faperta UGM. Yogyakarta.

[2] Nurcahya, A.O., Herlina, N. Dan Guritno, B. 2017. Pengaruh Macam Pupuk Organik dan Waktu Aplikasi terhadap Pertumbuhan dan Hasil Jagung Manis (Zea mays saccharata Sturt). Produsi Tanaman Vol 5 (9): 1476 1482

[3] Raksun, A. (2009). Pengaruh Pemberian Bokashi Terhadap Pertumbuhan Dan
Produksi Jagung (Zea mays). Jurnal Pijar Mipa, 4(2).

[4] Rizqullah, H., Sitawati dan Guritno, B. 2017. Pengaruh Macam dan Cara Aplikasi Pupuk Organik terhadap Pertumbuhan dan Produksi Tanaman Jagung Manis. Produksi Tanaman Vol 5 (3): 387 - 389

[5] Rahman, A.S., Nugroho, A. dan Soeslistyono, R. 2018. Kajian Hasil bawang Merah (Allium ascalonicum L) di Lahan dan Polybag dengan Pemberian Berbagai Macam Dosis Pupuk Organik. Produksi Tanaman Vol 4 (7): 538 - 546

[6] Hanafiah, 1991. K.A. Rancangan Percobaan. Teori dan Aplikasi. Fakultas Pertanian Universitas Sriwijaya. Palembang.

[7] Stevenson, F.J. 1992. Humus, Chemystry, Genesis, Compositions, Reactions. John Willy \& Sons. New York

[8] Karnan, Raksun, A. dan Japa, L. 2015. Respon Pertumbuhan Rumput Laut Euchema cottonii terhadap Pemberian Pupuk Organik Cair di Teluk Ekas Lombok Timur. Biologi Tropis Vol 15 (1): $39-46$

[9] Burhanuddin dan Nurahmansyah. 2010. Pengaruh pemberian pupuk kandang dan kapur terhadap pertumbuhan dan produksi nilam pada tanah podsolik merah kuning. Bul. Littro. 21 (2): 138 - 144

[10] Raksun, A. 2014. Aplikasi Pupuk Organik Cair untuk Meningkatkan Pertumbuhan Kedelai (Glycine max L). Biologi Tropis Vol 14 (2): $62-67$

[11] Raksun, A. 2016. Aplikasi Pupuk Organik untuk Meningkatkan Pertumbuhan Bibit Jambu Mete (Anacardium occidentale L). Biologi Tropis Vol 16 (2): 1 - 9

[12] Rakun, A., \& Mertha, I. G. (2018). Pengaruh Kompos Terhadap Hasil Panen Tomat (Lycopersicum esculentum Mill). Jurnal Pijar Mipa, 13(1), 56-59.

[13] Wahyunindyawati, F. Kasijadi dan Abu. 2012. Pengaruh pemberian pupuk organik biogreen granul terhadap pertumbuhan dan hasil tanaman bawang merah. Basic Science and Technology, 1 (1): 21 - 25.

[14] Hardjoko, D. 2002. Pengkajian Pupuk organik cair biogreenex pada tanaman sawi di Kabupaten Boyolali. Caraka Tani. 15 (2): 9 - 19

[15] Simatupang, Y.M.A. 1999. Pengaruh Pemberian Bokashi Kotoran Ayam dan Bokashi Rumput Terhadap Beberapa Sifat Fisika Tanah Podsolik Merah Kuning Gajrug dan Pertumbuhan Tanaman Kedelai (Glycine max L. Merr) varietas Wilis. Skripsi. Fakultas Pertanian Intitut Pertanian Bogor. 